\title{
KAJIAN TERHADAP PERDA BERMASALAH DARI SUDUT PANDANG HAM
}

\author{
H. Saripudin \\ Dosen Fakultas Hukum Universitas Widya Gama Mahakam Samarinda
}

\begin{abstract}
ABSTRAK
Perda yang baik bukanlah Perda yang eksklusif, sehingga kelak menjadi Perda yang bermasalah. Perda yang baik yang sesuai dengan indikator dari segi hukum Legislative Drafting yaitu dari perspektif hukum, sosio-politik, ekonomi dan hak asasi manusia (HAM) agar tidak bertentangan dengan prinsip Negara Kesatuan Republik Indonesia.
\end{abstract}

Kata Kunci : Perda Bermasalah, HAM

\section{PENDAHULUAN}

\section{A. Latar Belakang}

Suatu daerah pasti membutuhkan sumber pendapatan yang cukup, yang nantinya turut menunjang keberhasilan suatu daerah dalam pelaksanaan pembangunan maupun menunjang keberhasilan pelaksanaan Otonominya. Hal ini ditelusuri dari penjelasan umum Undang-Undang Nomor 32 Tahun 2004 sebagai berikut : Prinsip Otonomi daerah menggunakan prinsip otonomi seluas-luasnya dalam arti daerah diberikan kewenangan mengurus dan mengatur semua urusan pemerintahan di luar yang menjadi urusan Pemerintah yang ditetapkan dalam Undang-Undang ini. Daerah memiliki kewenangan membuat kebijakan daerah untuk memberi pelayanan, peningkatan peran serta, prakarsa, dan pemberdayaan masyarakat yang bertujuan pada peningkatan kesejahteraan rakyat.

Daerah diberi hak untuk mendapatkan sumber keuangan antara lain berupa : Kepastian tersedianya pendanaan dari pemerintah sesuai dengan urusan pemerintah yang diserahkan ; kewenangan memungut dan mendayagunakan pajak dan retribusi daerah dan hak untuk mendapatkan bagi hasil dari sumber-sumber daya nasional yang berada di daerah dan dana perimbangan lainnya ; hak untuk mengelola kekayaan Daerah dan mendapatkan sumber-sumber pendapatan lain yang sah serta sumbersumber pembiayaan. Dengan pengaturan tersebut, pada dasarnya Pemerintah menerapkan prinsip "Uang mengikuti fungsi".

Daerah-daerah otonom tersebut, seperti dikemukakan oleh RG Kartosapoetra, yaitu ; Daerah-daerah otonom harus dapat menggali sumber-sumber pendapatan atau keuangan sendiri agar supaya dapat memenuhi segala pembiayaan untuk penyelenggaraan dan pelaksanaan pembangunan di daerahnya. Pemerintah Pusat harus pula mempunyai sumber-sumber pendapatan yang cukup agar dapat menjalankan roda Pemerintahan Nasional disamping pembentukan dana-dana guna memberikan subsidisubsidi kepada masing-masing Daerah untuk menunjang pelaksanaan pembangunanpembangunan di Daerah dan menunjang pelaksanaan Otonominya. ${ }^{1}$

${ }^{1}$ RG. Kartosapoetra, Sistematika Hukum Tata Negara, Bina Aksara, Jakarta, 2002, hlm. 133 
Hubungan antara Pemerintah Pusat dan Daerah sangatlah kompleks, karena mencakup permasalahan yang sangat luas. Banyak faktor yang perlu dipertimbangkan unutuk merumuskan suatu sistem hubungan keuangan antara Pemerintah Pusat dan Daerah, baik faktor ekonomis dan politis pada khususnya. Kemandirian daerah dalam Pembiayaan daerah tidak dapat ditafsirkan bahwa tiap tingkatan pemerintahan di daerah harus dapat membiayai seluruh keperluannya dari pendapatan asli daerah.

Kebutuhan dana untuk pembangunan dan keperluan pembiayaan rutin daerah semakin meningkat sesuai dengan tingkat kebutuhan serta pertumbuhan yang diinginkannya. Berkaitan dengan kebutuhan dana tersebut di atas, maka suatu daerah harus mencari dana sebagai sumber pendapatan daerah karena pembangunan itu sendiri membutuhkan biaya yang tidak sedikit jumlahnya, sehingga setiap pemerintah daerah berusaha untuk mencari cela-cela potensi yang ada didaerah untuk dapat menarik dana dalam bentuk pajak daerah maupun retribusi untuk membiayai pembangunan tersebut.

Sebagai dasar untuk menarik dana tersebut Bupati/ walikota bersama dengan DPRD membuat Perda sebagai dasar hukum untuk penarikan dana tersebut di tengah masyarakat, Perda menjadi sandaran hukum bagi setiap daerah dalam melegalkan kebijakan yang dibuat oleh pemerintah daerah. Berdasarkan Undang-Undang Nomor. 10 Tahun 2004 Peraturan Daerah (Perda) adalah bentuk peraturan Perundangundangan yang berada di bawah undang-Undang, Perpu, Peraturan Pemerintah dan peraturan Presiden demikian juga didalam pasal 18 ayat (6) Undang-Undang Dasar Tahun 1945 "Pemerintah Daerah berhak menetapkan Peraturan Daerah dan Peraturan-peraturan lain untuk melaksanakan otonomi dan tugas pembantuan" 2

Pelaksanaan otonomi daerah berdasarkan Undang-Undang Nomor. 22 Tahun 1999 dan Undang-Undang Nomor. 25 Tahun 1999 yang telah diganti dengan Undang-Undang Nomor 32 Tahun 2004 dan Undang-Undang Nomor 33 Tahun 2004 tidak hanya semata-mata ditentukan oleh tingginya PAD. Namun ada faktor-faktor lain yang ikut menetukan seperti tingkat demokratisasi daerah, kemandirian daerah, dan kesejahteraan masyarakat daerah. ${ }^{3}$

Sepanjang perjalanan otonomi daerah banyak hal yang terjadi akibat pembuatan Peraturan Daerah (Perda) yang mengakibatkan Peraturan Daerah tesebut dibatalkan oleh Menteri Dalam Negeri atau Judicial Review ke Mahkamah Agung, Menurut catatan peneliti sejak Tahun 2002 sampai dengan September 2009 ada sebanyak 2123 Perda yang telah dibatalkan.

Sebagai konsekuensi dari sebuah Perda yang dikualifikasi bermasalah, maka Perda tersebut harus dibatalkan. Jika tidak, dianggap sebagai pungutan liar atau korupsi Pemerintah Daerah yang tetap memberlakukan Perda tersebut Berdasarkan uraian tersebut diatas Peneliti mengangkat tulisan ini dengan Judul " KAJIAN TERHADAP PERDA BERMASALAH DARI SUDUT PANDANG HAM"

\section{B. Rumusan Masalah}

Berdasarkan latar belakang masalah tersebut, maka dapat dirumuskan permasalahan sebagai berikut :

1. Bagaimana hubungan Pemerintahan daerah dengan HAM ?

2. Apakah Indikator Perda dianggap bermasalah di tinjau dari sudut pandang HAM ?

\footnotetext{
2 Jimly Asshidiqie, Perihal Undang-Undang, Konstitusi Press, jkt, hlm. 94.

${ }^{3}$ Jazim Hamidi, Indikator Peraturan daerah (PERDA) bermasalah yang mengahambat investasi ke daerah, makalah.
} 
1. Tujuan Penelitian

\section{Tujuan dan Kegunaan Penelitian}

a) Untuk mengetahui dan menganalisis Indikator Perda Retribusi bermasalah dari sudt pandang HAM tersebut .

b) Untuk mengetahui dan menganalisis Implikasi hukum Perda Tentang Retribusi yang bermasalah tersebut pada penyelenggaraan Pemerintah.

2. Kegunaan Penelitian

a) Teoritis.

1) Untuk menambah khasanan Ilmu pengetahuan terutama Hukum Tata Negara dan Legislative Drafting .

2) Sebagai bahan kajian dan masukan terhadap pembuatan Perda yang sedang dan akan dibuat oleh Pemkot Kota Samarinda

b) Praktis.

1) Sebagai bahan masukkan bagi Pemkot serta DPRD Kota .

2) Sebagai bahan rujukan bagi kalangan pengamat, LSM, pelaksana usaha dan anggota masyarakat yang memberikan perhatian terhadap kinerja Pemkot, serta DPRD Kota dalam rangka otonomi daerah.

\section{Batasan Masalah}

Penelitian ini difokuskan pada bidang Hukum Legislative Drafting khususnya dalam bidang pembuatan Perda dan Evaluasi Perda bermasalah. Adapun indikator Perda Retribusi yang dikualifikasikan bermasalah dari segi hukum legislative drafting itu berupa :

1. Perspektif Hukum

2. Perspektif sosio-politik

3. Perspektif Ekonomi

4. Perspektif HAM

\section{E. Definisi Konsepsional}

Untuk memberikan pedoman dalam pembahasan selanjutnya, maka perlu diberikan definisi konsepsional dari konsep-konsep terkait untuk menghindarkan salah pengertian yang mungkin timbul urgen daerah.dalam pembahasan penelitian ini. Definisi Operasional dari konsep-konsep adalah :

1. Perda (Peraturan Daerah ) adalah :

a. Menurut Undang-Undang Nomor 10 Tentang Pembentukan Peraturan Perundang Undangan: Peraturan Perundang-Undangan yang dibentuk oleh Dewan Perwakilan Rakyat Daerah dengan persetujuan Kepala Daerah.

b. Menurut Undang-Undang Nomor. 32 Tahun 2004 Tentang Pemerintahan Daerah dalam Pasal 1 Angka 10 adalah Peraturan Gubernur dan / Peraturan Bupati/Walikota.

2. Retribusi adalah :

a. Undang-Undang Nomor 34 Tahun 2000, retribusi daerah yang selanjutnya disebut retribusi, adalah pungutan daerah sebagai pembayaran atas jasa atau pemberian ijin tertentu yang khusus disediakan dan/ atau diberikan oleh pemeintah derah untuk kepentingan orang pribadi atau badan (Pasal 1 (1)).

b. Berdasarkan Pasal 1 ayat (28) Undang-Undang Nomor. 34 Tahun 2000 dinyatakan bahwa retribusi Daerah sebagai salah satu sumber penerimaan 
Daerah adalah pungutan daerahsebagai atas jasa atau pemberian izin tertentu yang khusus disediakan dan atau diberikan oleh Pemerintah Daerah untuk kepentingan orang pribadi atau badan.

3. Perda Bermasalah : adalah Perda yang dibatalkan / dicabut oleh Pemerintah Cq Mendagri. Adalapun indikatornya ada 4 macam yaitu Hukum (legislative Drafting), Ekonomi, Politik, dan Investasi Undang-Undang Nomor 34 Tahun 2000, retribusi daerah yang selanjutnya disebut retribusi, adalah pungutan daerah sebagai pembayaran atas jasa atau pemberian ijin tertentu yang khusus disediakan dan/ atau diberikan oleh pemeintah derah untuk kepentingan orang pribadi atau badan (Pasal $1(1))^{4}$

4. Implikasi Hukum: menurut pendapat Riza A. Putranto: Implikasi berarti kaitan atau akibat. Jadi implikasi hukum adalah kaitan atau akibat hukum. ${ }^{5}$

5. Evaluasi: adalah penilaian kualitas dari keberhasilan pelatihan/ pekerjaan/ kegiatan yang telah dilakukan ${ }^{6}$

6. Indikator: Panduan untuk menerapkan analisa multikriteria dalam menilai. ${ }^{7}$

\section{TINJAUAN PUSTAKA}

\section{A. Pengertian Retribusi.}

Dalam menunjang pelaksanaan pembangunan diberbagai aspek, Pemerintah Kota Samarinda berupaya mendapatkan dana untuk membiayai pembangunan, salah satunya adalah menetapkan Peraturan Daerah mengenai Retribusi.

Sri Pudyatmoho Y. Dalam bukunya Pengantar Hukum Pajak menjelaskan bahwa retribusi agak berbeda dengan pajak, dalam retribusi hubungan antara prestasi yang dilakukan (dalam wujud pembayaran) dengan kontraprestasi itu bersifat langsung. Dalam hal ini pembayaran retribusi justru menginginkan adanya jasa timbal balik secara langsung dari pemerintah sebagai contoh adalah pembayaran air minum pada PDAM, retribusi listrik, telpon, gas pengenaan retribusi juga dilakukan dengan pengenaan berdasarkan kepada ketentuan-ketentuan yang berlaku secara umum dan untuk menaatinya yang bersangkutan dapat dipaksa. ${ }^{8}$

Sri Pudyatmoho Y lebih lanjut menjelaskan bahwa ada ciri-ciri tertentu yang melekat pada retribusi, antara lain :

1. Retribusi dipungut dengan berdasarkan peraturan-peraturan (yg berlaku secara umum).

2. Dalam retribusi, prestasi yang berupa pembayaran dari warga masyarakat akan mendapatkan jasa timbal balik secara langsung yang tertuju pada indiviud yang membayarnya.

3. Uang hasil dari retribusi dipergunakan bagi pembayaran umum berkaitan dengan retribusi yang bersangkutan.

4. Pelaksaan dapat dipaksakan, dimana paksaan itu umumnya bersifat ekonomis. ${ }^{9}$

\footnotetext{
${ }^{4}$ Jazim Hamidi, Indikator Peraturan Daerah (Perda) Bermasalah Yang Menghambat Investasi ke daerah, makalah, hlm. 6, tanpa tahun.

${ }^{5}$ Rizaputranto.bllogs.friendster.com $/ \mathrm{m}$.

${ }^{6}$ www.ica-sae-org/trainer/indonesian

${ }^{7}$ www.cifor.cg/ar.org/publikcationade

${ }^{8}$ Sri Pudyatmoho Y, Pengantar Hukum Pajak, 2005, hlm, 5

${ }^{9}$ Ibid.
} 
Soesilo Prayogi dalam bukunya Kamus Hukum Internasional dan Indonesia menyatakan bahwa retribusi adalah iuran yang dibayarkan sebagai pengganti jasa pemerintah telah memberikan ijin sesuatu kepada pemakai, misalnya pemasangan papan reklame dipinggir jalan, kendaran intercity yang melewati terminal-terminal bus yang dilaluinya semuanya membayar retribusi kepada pemerintah daerah . ${ }^{10}$

Didalam peraturan umum pajak daerah dan retribusi derah Undang-Undang Nomor 34 Tahun 2000, retribusi daerah yang selanjutnya disebut retribusi, adalah pungutan daerah sebagai pembayaran atas jasa atau pemberian ijin tertentu yang khusus disediakan dan/ atau diberikan oleh pemeintah derah untuk kepentingan orang pribadi atau badan (Pasal 1 (1))

Pemeintah Kota Samarinda, retribusi diatur dalam peraturan daerah tentang retribusi daerah kota samarinda yang saat ini berlaku masih bermasalah, karena menurut peneliti terdapat beberapa ketentuan yang belum berlaku sebagaimana mestinya.

Dalam implementasinya restribusi daerah telah diatur didalam peraturan pemerintah Republik Indonesia Nomor 66 Tahun 2001 tentang restrbusi daerah , namun dalam pelaksanaannya masih harus dilihat kembali karena ada yang tidak sesuai dengan prateknya.

Dalam pelaksanaanya kecenderungan masyarakat terkadang tidak dapat membedakan antara restribusi, pajak dan sumbangan

Rochmat soemitro, yang dikutip oleh Sri Pudyatmoko dalam bukunya pengantar hukum pajak, bahwa pajak adalah iuran rakyat kepada kas negara berdasarkan undang-undang yang dapat dipaksakan dengan tidak mendapat jasa timbal balik (kontra prestasi), yang langsung dapat ditujukan dan yang digunakan untuk membayar pengeluaran umum. ${ }^{11}$ Sri pudyatmoko.Y, memberikan beberapa ciri-ciri pajak sebagai berikut:

1. Pajak dipungut berdasarkan Undang-undang atau peraturan pelaksanaannya.

2. Terhadap pembayaran pajak, tidak ada tegen prestasi yang dapat ditunjukan secara langsung.

3. Pemungutan dapat dilakukan baik pemerintah pusat maupun pemerintah daerah.

4. Hasil uang pajak dipergungakan untuk membiayaai pengeluaran-pengeluaran pemerintah baik pengeluaran rutin maupun pengeluaran pembangunan. ${ }^{12}$

Sedangkan sumbangan menurut Santoso Brotodiharjo, didalam sumbang terdapat pemikiran bahwa biaya-biaya yang dikeluarkan untuk prestasi pemerintah tertentu, tidak boleh dikeluarkan dari kas umum, karena prestasi itu tidak ditujukan kepada penduduk seluruhnya, melainkan hanya untuk sebagian tertentu saja. Oleh karenanya, hanya golongan tertentu dari Penduduk ini sajalah yang diwajibkan membayar sumbangan ini. ${ }^{13}$

\section{B. Dasar Keberlakuan Peraturan Perundang-Undangan}

Peraturan perundang-Undangan tertulis menempati posisi yang penting dalam kancah hukum modern saat ini. Sebagai salah satu sumber hukum, Peraturan perundang-Undangan tidak selalu menjunjung tinggi keadilan, demokrasi dan

\footnotetext{
${ }^{10}$ Soesilo Prayogi, Kamus Hukum Internasional dan Indonesia, 2007, hlm. 427

11 Sri Pudyatmoko, Loc.cit, hlm 2.

12 Ibid. Hlm. 4

${ }^{13}$ Ibid.
} 
kepentingan masyarakat luas, karena hukum bukanlah subsistem yang otonom dan netral tetapi selalu dipengaruhi banyak faktor dan kepentingan. Dalam kajian ilmu hukum paling tidak ada 3 faktor yang menjadi parameter sebuah peraturan perundang-undangan dapat berlaku secara baik yaitu :

1. Keberlakuan Yuridis.

Keberlakuan yuridis atau normatif suatu peraturan atau kaidah jika kaidah itu merupakan bagian dari suatu kaidah hukum tertentu yang didalam kaidah-kaidah hukum saling menunjuk yang satu terhadap yang lain. Sistem kaidah hukum yang demikian ini terdiri atas suatu keseluruhan hirarki kaidah hukum khusus yang bertumpu pada kaidah hukum umum. Di dalamnya kaidah hukum khusus yang lebih rendah diderivasi dari kaidah hukum yang lebih tinggi. ${ }^{14}$

Keberlakuan yuridis dari kaidah hukum oleh Bagir Manan diperinci dalam syaratsyarat:

a) Pertama, keharusan adanya kewenangan dari pembuat peraturan perundangundangan. Setiap peraturan perundang-undangan harus dibuat oleh badan atau pejabat yang berwenang. Jika tidak maka peraturan perundang-undangan tersebut batal demi hukum. Dianggap tidak pernah ada dan segala kibatnya batal secara hukum.

b) Kedua, keharusan adanya kesesuaian bentuk atau jenis atau peraturan perundang-undangan dengan materi yang diatur, terutama kalau perintah oleh peraturan perundang-undangan tingkat lebih tinggi ata sederajat. Ketidak sesuaian bentuk ini dapat menjadi alasan untuk membatalkan peraturan perundang-undangan tersebut.

c) Ketiga, keharusan mengikuti tata cara tertentu. Apabila tata cara tersebut tidak diikuti, maka peraturan perundang-undangan tersebut batal demi hukum atau tidak/ belum memiliki kekuatan hukum yang mengikat.

d) Keempat, keharusan tidak bertentangan dengan peraturan perundang-undangan yang lebih tinggi tingkatannya. ${ }^{15}$

Dalam kaitan dengan dasar berlaku secara yuridis dari peraturan perundangundangan maka Soerjono Soekanto dan Purnadi Purbacaraka mengemukakan beberapa pendapat :

a) Hans kelsen berpendapat bahwa setiap kaidah hukum harus berdasarkan kaidah yang lebih tinggi tingkatannya.

b) W. Zevenbergen menyatakan bahwa setiap kaidah hukum harus memenuhi syarat-syarat pembentukannya.

c) Logemann, kaidah hukum mengikat kalau menunjukkan hubungan keharusan antara satu kondisi dengan akibatnya ${ }^{16}$.

2. Keberlakuan Emperis.

Dasar berlaku secara emperis/ sosiologis maksudnya adalah jika para warga masyarakat mematuhi hukum dimana hukum itu diberlakukan. Keberlakuan emperis dapat dilihat melalui sarana penelitian emperis tentang perilaku warga masyarakat. Jika dari penelitian tersebut tanpak bahwa masyarakat berperilaku dengan mengacu kepada kseluruhan kaidah hukum, maka terdapat keberlakuan emperis kaidah hukum. Dengan demikian norma mencerminkan kenyataan yang hidup dalam masyarakat.

\footnotetext{
${ }^{14}$ J.J.H.Bruggink, Refleksi hukum, Citra Aditya Bakti, Bdn, 1996, hlm. 150-152.

Bagir manan, Peran Hakim Dalam Dekolonisasi hukum, dalam I.s. Susanto dan Bernard L. Tanya (ed). Wajah hukum di Era Reformasi (kumpulan karya Ilmiah menyambut 70 tahun Prof.DR. Satjipto Rahatdjo,SH, Citra Aditya Bakti, bdn, 2000, hlm 14-15.

Soerjono Sukanto, Purnadi Purbacaraka, Perihal kaidah Hukum , Citra Aditya Bakti, Bdn, 1993, hlm. 88-89
} 
Dengan dasar sosiologis peraturan perundangan-undangan yang dibuat dan diterima oleh masyarakat secara wajar bahkan spontan. Soerjono Soekanto dan Purnadi Purbacaraka mencatat dua landasan teoritis sebagai dasar sosiologis berlakunya suatu kaidah hukum, yaitu:

a) Teori Kekuasaan, secara sosiologis kaidah hukum berlaku karena paksaan penguasa, terlepas diterima atau tidak oleh masyarakat.

b) Teori Pengakuan, kaidah hukum berlaku berdasarkan penerimaan dari masyarakat tempat hukum itu berlaku. ${ }^{17}$

Friedman menyebutkan bahwa paling tidak ada 3 (tiga) faktor yang cukup cukup dominan yang mempengaruhi proses penegakan hukum, yakni:

Pertama, faktor substansi hukum. Substansi disini dimaksudkan adalah aturan, norma, pola perilaku nyata manusia yang berada dalam sistem itu. Substansi juga berarti produk yang dihasilkan oleh orang yang berada dalam sistem hukum itu, mencakup keputusan yang mereka keluarkan, aturan baru yang mereka susun. Substansi juga mencangkup living law dan bukan hanya aturan yang ada dalam Kitab UndangUndang.

Kedua, faktor struktural dalam hal ini adalah bagian yang tetap bertahan, bagian yang memberi semacam bentuk dan batasan terhadap keseluruhan . Di Indonesia misalnya jika kita berbicara tentang struktur sistem hukum Indonesia maka termasuk didalamnya struktur institusi penegak hukum seperti Kepolisian, Kejaksaan dan Pengadilan. Juga termasuk unsur struktur jumlah dan jenis Pengadilan, Yurisdiksinya. Ketiga, faktor kultural dalam hal ini sikap manusia dan sistem hukum kepercayaan, nilai pemikiran serta harapannya. Dengan kata lain kultur hukum adalah suasana pikiran sosial yang menentukan bagaimana hukum digunakan, dihindari atau disalahgunakan. tanpa kultur hukum maka hukum tidak berdaya.

3. Keberlakuan Filosofis.

Setiap masyarakat selalu mempunyai "Rechtsidee" Yakni apa yang masyarakat harapkan dari hukum, misalnya hukum diharapkan untuk menjamin adanya keadilan, kemanfaatan dan ketertiban maupun kesejahteraan. Cita hukum atau "Rechtsidee" tumbuh dalam sistem nilai masyarakat tentang baik dan buruk, pandangan mereka menenai hubungan individu dan kemasyarakat dan lain sebagainya termasuk pandangan tentang dunia gaib. Semua ini bersifat filosofis, artinya menyangkut pandangan mengenai inti atau hakikat sesuatu. Hukum diharapkan mencerminkan sistem nilai baik sebagai sarana yang melindungi nilai-nilai maupun sebagai sarana mewujudkannya dalam tingkah laku masyarakat.

\section{Asas-asas dalam Pembentukan Peraturan Perundang-Undangan yang Baik.}

Gagasan tentang asas hukum sebagai kaidah penilaian fundamental dalam suatu sistem hukum kita temukan kembali dari banyak teori hukum. Paul Schollten menguraikan asas hukum sebagai pikiran-pikiran dasar, yang terdapat didalam dan dibelakang sistem hukum masing-masing dirumuskan dalam aturan-aturan perundangundangan dan putusan-putusan hakim yang berkenaan dengan ketentuan-ketentuan dan keputusan-keputusan individual dapat dipandang sebagai penjabarannya. ${ }^{18}$

Satjipto Rahardjo menyatakan bahwa asas hukum merupakan "jantungnya" peraturan hukum. Karena menurut Satjipto asas hukum adalah landasan yang paling

\footnotetext{
${ }^{17}$ Soerjono Soekanto dan Purnadi Purbacaraka, Ibid. 91-92.

${ }^{18}$ J.J.H.Bruggink, Refleksi tentang hukum, Bdng, Citra Aditya bakti, 1996,hlm. 119
} 
luas bagi lahirnya suatu peraturan hukum. Ini berarti, bahwa peraturan-peraturan hukum itu pada akhirnya bisa dikembalikan kepada asas-asas tersebut. Kecuali disebut landasan, asas hukum layak disebut sebagi alasan bagi lahirnya peraturan hukum, atau merupakan ratio legis dari peraturan hukum. Asas hukum tidak akan habis kekuatannya dengan melahirkan suatu peraturan hukum, melainkan akan tetap saja ada dan akan melahirkan peraturan-peraturan selanjutnya. ${ }^{19}$

Oleh karena itu paton menyebutkannya sebagai suatu sarana membuat hukum itu hidup, tumbuh dan berkembang dan ia menunjukkan, bahwa itu bukan sekedar kumpulan dari peraturan-peraturan belaka. Kalau dikatakan, bahwa dengan adanya asas hukum, hukum itu bukan merupakan sekedar kumpulan peraturan-peraturan maka hal itu disebabkan oleh karena asas itu mengandung nilai-nilai dan tuntutantuntutan etis. Apabila kita membaca suatu peraturan hukum, mungkin kita tidak menemukan pertimbangan etis disitu. Tetapi asas hukum menunjukkan adanya tuntutan etis yang demikian itu, atau setidak-tidaknya kita bisa merasakan adanya petunjuk kearah itu. ${ }^{20}$

Bruggink menyatakan bahwa peranan dari asas hukum sebagai meta-kaidah berkenan dengan kaidah hukum dalam bentuk kaidah perilaku. Namun yang menjadi pertanyaan adalah apakah asas hukum itu harus dipandang sebagai bentuk yang kuat atau yang lemah dari meta-kaidah. ${ }^{21}$

Dalam hal pertama, asas hukum dapat dipandang sebagai suatu tipe kaidah berkenaan dengan kaidah perilaku dan dengan demikian secara prinsip dapat dibedakan dari jenis kaidah ini. Mereka yang menganut pandangan ini, misalnya menunjuk asas hukum sebagai kaidah argumentasi berkenaan dengan penerapa kaidah perilaku. Asas-asas hukum hanya akan memberikan argumen-argumen bagi pedoman perilaku yang harus diterapkan dan asas-asas itu sendiri tidak memberikan pedoman.

Dalam hal kedua, asas-asas hukum itu tampaknya dapat dianggap termasuk dalam tipe kaidah yang berkenaan dengan kaidah perilaku, namun memiliki juga fungsi sejenis seperti kaidah perilaku. Jadi hanya terdapat suatu perbedaan gradual saja antara asas hukum dan kaidah perilaku. Dalam pandangan ini maka asas hukum adalah kaidah yang berpengaruh terhadap kaidah perilaku, karena asas hukum ini memainkan peranan pada interprestasi terhadap aturan hukum dan dengan itu menentukan wilayah penerapan kaidah hukum. Berdasarkan itu maka asas dapat dinyatakan termasuk tipe meta kaidah. Asas hukum juga sekaligus merupakan perpanjangan dari kaidah perilaku, karena asas hukum juga memberikan arah pada perilaku yang dikehendaki.

Para ahli juga memberikan uraian tentang beberapa perbedaan antara asas hukum dengan kaidah perilaku. Pendapat yang banyak dianut oleh para teeoritis adalah bahwa asas hukum bersifat umum sedangkan kaidah perilaku yang bersifat khusus. Dengan umum dimaksudkan bahwa asas hukum memiliki wilayah penerapan yang lebih luas ketimbang kaidah perilaku. Makin besar wilayahnya, makin lebih umum kaidah hukumnya, makin lebih abstrak aturan hukum yang dirumuskannya.

Dalam suatu sitem hukum, maka asas hukum sebagai kaidah penilaian fundamental adalah kaidah hukum yang paling umum. Bahwa suatu kaidah hukum adalah "umum", berarti bahwa ia dalam penerapannya harus dikhususkan dengan mengarahkannya pada situasi faktual. Ini sesungguhnya berarti bahwa kaidah hukum itu tidak cukup jelas mengharuskan, bagaimana orang seharusnya berperilaku dalam situasi faktual itu. Dalam hal kaidah perilaku yang terjadi justru sebaliknya. Kaidah

\footnotetext{
${ }^{19}$ Satjipto Rahardjo, Ilmu Hukum, Bdng, Alumni, 1986.hlm. 85.

${ }^{20}$ Satjipto Rahardjo, Ibid..

${ }^{21}$ J.J.H. Bruggink.Op.Cit.hlm. 120.
} 
hukum yang khusus ini, yang timbul dari aturan hukum yang dirumuskan lebih konkrit, memberikan pedoman yang lebih jelas bagi perbuatan. Asas hukum sebagai kaidah hukum yang umum hanya memberikan suatu ukuran nilai. Ukuran nilai itu baru didalam kaidah perilaku sebagai kaidah hukum yang khusus memperoleh bentuk yang sedemikian rupa, sehingga memunculkan pedoman yang jelas bagi perbuatan, misalnya dengan jalan memberikan suatu hak atau meletakan suatu kewajiban.

Perbedaan kedua antara asas hukum dan kaidah perilaku anatara lain diajukan oleh Paul Scholten dan berada dalam garis pikiran dari perbedaan pertama. Scholten berpendapat bahwa aturan hukum memiliki isi yang jauh lebih konkrit, yang menyebabkan aturan itu dalam penemuan hukum yang dapat diterapkan secara langsung. Berlawanan dengan itu asas hukum dalam penemuan hukum memiliki daya kerja secara tidak langsung, yakni menjalankan pengaruh pada interprestasi terhadap aturan hukum. Aturan hukum terbentuk karena pembentuk undang-undang dalam pembentukan aturannya atau hakim dalam pengambilan putusan hukumnya menimbang-nimbang berbagai asas hukum yang satu terhadap yang lain.

P.W.Brouwer menyebutkan perbedaan antara asas hukum dan aturan hukum terdapat dalam kekuatan Inferensial.$^{22}$ selanjutnya ia menunjukkan bahwa perbedaan ini tidak dapat dijabarkan dari perumusan dari ukuran, melainkan dari cara bagaimana orang menggunakan aturan tersebut. Sebagai contoh ia mengajukan ukuran " tiada hukum tanpa kesalahan', kita menggunakan ukuran ini sebagai aturan, jika kita menerima bahwa ketidakberadaan kesalahan secara logis niscaya dengan sendirinya membawa pada kesimpulan bahwa tiada hukuman boleh dijatuhkan. Kita menggunakan ukuran ini sebagai asas, jika kita menganggap ketidakberadaan kesalahan sebagai alasan untuk eventual tidak menjatuhkan hukuman, tetapi alasan ini tidak perlu selalu harus diikuti.

Dalam perspektif pembentukan peraturan, Montesquieu dalam karyanya L"esperit des Lois mengemukakan sejumlah persyaratan yang harus dipenuhi dalam pembentukan peraturan perundang-undangan, yakni: ${ }^{23}$

1. Gaya penuturannya hendaknya padat dan sederhana, ini mengandung arti bahwa pengutaraannya dengan menggunakan ungkapan kebesaran dan retorik hanya merupakan tambahan yang menyesatkan dan mubazir;

2. Istilah-istilah yang dipilih hendaknya bersifat mutlak dan relatif, sehingga dengan demikian memperkecil kemungkinan munculnya perbedaan pendapat yang individual;

3. Hukum hendaknya membatasi diri pada hal-hal yang riil dan aktual dengan menghindari hal-hal yang bersifat metaforis dan hipotetis;

4. Hukum hendaknya tidak dirumuskan dalam bahasa yang tinggi, oleh karena ia ditujukan kepada rakyat yang memiliki tingkat kecerdasan rata-rata, bahasa hukum tidak untuk latihan penggunaan logika melainkan hanya penalaran sederhanayang bisa dipahami oleh orang rata-rata;

5. Hukum hendaknya tidak merancukan pokok masalah dengan pengecualian, pembatasan atau pengubahan, gunakan semua itu jika benar-benar diperlukan;

6. Hukum hendaknya tidak bersifat debatable karena hal tersebut akan menimbulkan konflik.

7. Lebih dari semua, pembentukan hukum hendaknya mempertimbangkan masakmasak dan mempunyai manfaat praktis dan hendaknya tidak menggoyahkan sendi-sendi pertimbangan dasar keadilan dan hakekat pemasalahan sebab hukum

\footnotetext{
${ }^{22}$ Sirajuddin, Fatkhurahman,zulkarnain, Modul Legislative Drafting, Fakultas Hukum Universitas Widyagama malang, 2005, hlm.22.

${ }^{23}$ ibid.
} 
yang lemah idak perlu dan tidak adil akan membawa seluruh sistem perundangaundangan mendapat citra buruk dan menggoyahkan legitimasi negara.

Lebih lanjut terdapat delapan azas atau Principle of legality yang disebutkan oleh Lon L. Fuller dalam bukunya Morality of law, yaitu :

1. Suatu sistem hukum harus mengandung peraturan-peraturan;

2. Peraturan-peraturan yang telah dibuat itu harus diumumkan;

3. Tidak boleh ada peraturan yang berlaku surut, oleh karena apabila yang demikian itu tidak ditolak, maka peraturan itu tidak bisa dipakai untuk menjadi pedoman tingkah laku;

4. Peraturan-peraturan harus disusun dalam rumusan yang bisa dimengerti;

5. Suatu sistem tidak boleh mengandung peaturan-peraturan yang bertentangan satu sama lain;

6. Peraturan-peraturan tidak boleh mengandung tuntutan yang melebihi apa yang dapat dilakukan.

7. Tidak boleh ada kebiasaan untuk sering merubah-merubah peraturan sehingga menyebabkan seorang akan kehilangan orientasi;

8. Harus ada kecocokan antara peraturan yang diundangkan dengan pelaksanaan sehari-hari. ${ }^{24}$

\section{PEMBAHASAN}

\section{A. Hubungan Pemerintahan daerah dengan HAM.}

Sebagaimana kita ketahui bahwa tujuan dibuatnya sebuah Perda adalah untuk mengatur dan melegalkan retrubusi atau pajak yang dibuat oleh kabupaten/ Kota didaerah dengan Perda itu sebagai landasan hukum untuk melakukan penarikan dana dari masyarakat yang tentunya hasilnya nanti dipergunakan untuk kesejahteraan masyarakat.

Didalam penarikan retribusi dari masyarakat tidak mengenal apakah itu masyarakat pendatang atau asli dan tidak mengenal agama, suku, ras tertentu karena Perda dibuat untuk semua lapisan masyarakat.

Setelah retribusi atau pajak daerah itu di kumpul sesuai dengan tujuannya untuk kesejahteraan masyarakat, hal ini tentunya tidak akan menimbulkan permasalahan, hal ini akan menimbulkan permasalahan jika ada beberapa anggota dewan atau Pemerintah Daerah baik itu Kabupaten atau Kota untuk mengusulkan membuat Perda yang bersifat Eklusif yaitu hanya untuk satu golongan tertentu saja yang diistimewakan hal ini tentunya akan menyakitkan golongan yang lain yang ikut menyumbang atau membayar retribusi pada daerah tersebut. Contoh perda Kabupaten Polewali mandar No. 14 tahun 2006 yang mana isi perda tersebut ada kewajiban masyarakat polewali mandar untuk bisa baca tulis Alquran yang dibuktikan dengan sertifikat yang dikeluarkan oleh lembaga yang dibentuk oleh pemerintah daerah,. Jika tidak bisa menunjukkan sertifikat tersebut anak-anak sekolah tidak bisa melanjutkan kejenjang yang lebih tinggi dan bagi pasangan yang ingin menikah tidak bisa melangsungkan pernikahan hal ini tentunya sangat melanggar HAM masyarakat kabupaten Polewali

${ }^{24}$ Pendapat Fuller dikutip oleh satjipto raharjo dalam bukuny, Ilmu Hukum, Almuni, bdng, 1986, hlm. 91-92. 
mandar tersebut terutama dalam bidang pendidikan dan berkeluarga sebagaimana di amanahkan didalam UUD 1945

Jika Perda tersebut tidak dianulir hal ini akan menimbulkan gejolak di tengah masyarakat yang akhirnya akan menimbulkan perpecahan dalam Negara kesatuan Republik Indonesia. Karena masing-masing daerah, suku dan agama akan membuat Perda yang eksklusif untuk golongan mereka. Dan hal ini bertentangan dengan tujuan Negara Republik ini didirikan yang dapat kita lihat didalam pembukaan UUD 1945 antara lain :

1. Melindungi segenap Bangsa dan seluruh tumpah darah Indonesia.

2. Memajukan Kesejateraan Umum,

3. Mencerdaskan kehidupan bangsa,

4. Ikut melaksanakan ketertiban dunia berdasarkan kemerdekaan, perdamaian abadi dan keadilan sosial.

Jika terjadi adanya hak eklusif yang diberikan kepada kelompok, golongan, rasa atau agama tertentu hal ini tentunya akan bertentangan tujuan dibentuk Negara ini khususnya butir 2 memajukan kesejahteraan umum dan jelas akan bertentangan juga dengan Pasal 1 ayat (3) Undang-Undang Dasar 1945 negara Indonesia adalah Negara hukum dan juga bertentangan dengan ciri-ciri Negara hukum menurut Julius Stahl salah satunya adalah adanya jaminan Hak Asasi Manusia.

Selain hal tersebut kita juga harus menyadari bahwa di bentuknya Negara ini bukan hanya sekedar pengisapan Negara kepada masyarakatnya jika kita membaca teori Kontrak Sosial John Locke bahwa Negara mendapat mandate (kontrak sosial) dari rakyat untuk menjalankan/ mengelola Negara/ pemerintahan dengan tujuan untuk kesejahteraan rakyat. Dari kontrak sosial yang dibuat ini maka lahirlah apa yang menjadi kewajiban Negara antara lain :

1. Kewajiban menghormati, Kewajiban menghormati dalam artian Negara wajib menghormati setiap hak-hak dasar masyarakat apa yang telah dia peroleh turuntemurun

2. Kewajiban untuk melindungi, Kewajiban untuk melindungi adalah Negara wajib untuk melindungi warganegaranya dimana dia berada,

3. Kewajiban untuk memenuhi, Kewajiban untuk memenuhi adalah kewajiban untuk memenuhi kebutuhan dasar setiap warganegaranya.

Dari apa yang telah diuraikan diatas, jelaslah bahwa setiap Perda yang memberikan Hak Eklusif kepada golongan, kelompok, ras agama tertentu hal ini tentunya akan menimbulkan pelanggaran HAM bagi anggota kelompok, golongan, ras, agama yang lain karena adanya diskriminasi tersebut. Dan bertentangan dengan UUD 1945 pasal 1, 15, 17, Undang-Undang No. 39 tahun 1999 Tentang HAM. Asas-asas umum pemerintahan yang baik di Indonesia, Undang-Undang No. 28 tahun 1994 tentang penyelenggaraan Negara yang bersih dan Bebas dari KKN, Peraturan Pemerintah No. 101 tahun 2000, Undang-Undang No. 30 Tahun 2002 tentang KPK, Undang-Undang No. 32 tahun 2004 Tentang Pemerintahan Daerah khususnya Pasal 20.

\section{B. Indikator Perda dianggap Bertentangan Dengan HAM .}

Adapun indikator Perda dianggap bertentangan dengan HAM dapat penulis sajikan ;

a) Dalam Bidang Pendidikan : UUD 1945 pasal $28 \mathrm{C}(1)$, pasal $31(1,3)$ UndangUndang No. 39 Tahun 1999 Undang-Undang -Undang No. 20 tahunj 2003 tentang Sisdiknas, Undang-undang No. 11 tahun 2005. 
b) Dalam Bidang Kesehatan : UUD 1945 Pasal 28 A, pasal 28B (2), pasal 28 H(1,2),Pasal 34 (3), Undang-undang No. 39 Tahun 1999, Undang-Undang No. 11 tahun 2005, Undang-Undang 23 Tahun 1992.

c) Dalam Bidang Pekerjaan Umum : UUD 1945 Pasal 28 H (1,2 dan 3), Pasal 33 (2,3 \& 4), Pasal 34 (3), Undang-Undang No. 39 tahun 1999, Undang-Undang 11 tahun 2005.

d) Dalam Bidang Penataan Ruang : UUD 1945 pasal 28, F, H (1), UndangUndang 39 tahun 1999 Pasal 9 (3).

e) Lingkungan Hidup : UU 1945 Pasal 28 F, H (1), Undang-Undang 39 tahun 1999, Undang-Undang No. 11 tahun 2005.

f) Perencanaan Pembangunan : UUD 1945 pasal $28 \mathrm{H}, \mathrm{F}$, Undang-Undang No. 29 tahun 1999, Undang-Undang No. 11 tahun 2005, Undang-Undang No. 4 tahun 1992.

g) Perumahan : UUD 1945 pasal 28 H (1), UU No. 39 tahun 1999, UU No. 11 tahun 2005 , UU No. 4 tahun 1992

h) Kepemudaan dan Olah Raga : UUD 1945 pasal 28 C (1\&2), Undang-Undang No. 39 Tahun 1999, Undang-Undang No. 3 tahun 2003.

i) Penanaman Modal : UUD 1945 Pasal 33 (1,2,3 dan 4)., UU No. 39 Tahun 1999, Undang-Undang No. 11 Tahun 2005, Undang-Undang No. 25 tahun 2007, TAP MPR No. XVI/ MPR/ 1998.

j) Koperasi dan Usaha Kecil dan Menengah : UUD 1945 Pasal 33 (1,2,3 dan 4), UU No. 39 / 1999.

k) Kependudukan dan Catatan Sipil : UUD 1945 pasal 28 D (4), UU No. 39, UU No. 12 Tahun 2005 dan UU No. 12 tahun 2006, UU No. 23 tahun 2002.

1) Ketenagakerjaan : UUD 1945 pasal 27 (2), pasal 28 D, E, (3), Undang-Undang No. 39 tahun 1999, Undang-Undang No. 11 tahun 2005, Undang-Undang No. 13 tahun 2003, Undang-Undang No. 23 tahun 1992.

m) Pertanian dan Ketahanan Pangan : UUD 1945 pasal 28 F pasal $33(2,3)$ Undang-Undang No. 11 tahun 2005 Undang-Undang No. 7 tahun 1996.

n) Pemberdayaan : UUD 1945 pasal 28 B (2), pasal 34 (2) UU No. 39 tahun 1999, Undang-Undang No. 31 tahun 2002 Undang-Undang No. 13 tahun 2003, Undang-Undang No. 11 tahun 2005, Undang-Undang 23 tahun 2002, Undang-Undang No. 3 tahun 1997 dan Undang-Undang No. 4 tahun 1979.

o) Keluarga berencana dan keluarga Sejahtera : UUD 1945 pasal 28 B, pasal 28 H (1), Undang-Undang No. 39 tahun 1999, Undang-Undang No. 12 tahun 2005.

p) Perhubungan : UUD 1945 pasal 34 (3), UU No. 14 tahun 92.

q) Komunikasi dan Informatika : UUD 1945 pasal $28 \mathrm{~F}$, Undang-Undang 39 tahun 1999, Undang-Undang 36 tahun 1999.

r) Pertanahan : UUD 1945 pasal 33 (1,2,3), UU No. 39 tahun 1999, UndangUndang No. 5 tahun 1960.

s) Kesatuan Bangsa dan Politik Dalam Negeri : UUD 1945 Pasal 20, pasal 28 , pasal 28E (1,2) Undang-undang No. 12 tahun 2005.

t) Otonomi Daerah ; UUD 1945 pasal 18, pasal 18 A, pasal 28 D (3), UU No. 39 tahun 1999, Undang-Undang No. 32 tahun 2004.

u) Pemberdayaan Masyarakat dan Desa : UUD 1945 Pasal 28 C, pasal 34 (2), UU No. 29 tahun 1999, Undang-Undang No. 39 tahun 1999, Undang-Undang No. 6 tahun 1974 . 
Inilah indikator yang dipergunakan didalam mengevaluasi Perda-Perda yang dibuat oleh Pemerintah kabupaten / Kota jika dihubungkan dengan Hak asasi manusia.

\section{PENUTUP}

Perda yang baik adalah yang tidak saja sesuai dengan yuridis, sosial dan ekonomi tetapi juga Perda yang menghormati Hak Asasi manusia, masyarakat dimana Perda tersebut diberlakukan dan didalam UUD 1945 dan di berbagai peraturan Perundang;Undangan ada indikator sebagai landasan didalam pembuatan Perda tersebut.

\section{A. LITERATUR.}

\section{DAFTAR PUSTAKA}

A.Hakim G.Nusantara " Kebijaksanaan dan Strategi Pembangunan Hukum di Indonesia, Sebuah Tinjauan Kritis politik Pembangunan Hukum Nasional" dalam Artidjo Alkostar dan M.Sholeh Amin (ed). Pembangunan Hukum Dalam Perspektif Politik Hukum nasional, LBH Yogyakarta berkerjasama dengan rajawali Pers, Jakarta, 1986.

Bagir manan, Dasar-dasar Perundang-Undangan Indonesia, IN-HILL-Co, Jkt, 1992.

, Peran Hakim Dalam Dekolonisasi hukum, dalam I.s. Susanto dan Bernard L. Tanya (ed). Wajah hukum di Era Reformasi (kumpulan karya Ilmiah menyambut 70 tahun Prof.DR. Satjipto Rahatdjo,SH, Citra Aditya Bakti, bdn, 2000

Dahlan Thaib.H, Jazim Hamidi, Ni'matul Huda.Hj, Teori dan Hukum Konstitusi, Rajawali Pers, Jakarta, 2001.

Dasril radjab, Hukum tata Negara Indonesia, Rineka Cipta, Jakarta, 2005

Erman Radjagukguk, 2000, Peranan Hukum di Indonesia: Menjaga Persatuan, memulihkan Ekonomi dan Memperluas Kesejahteraan Sosial, UI, Jkt, 2000.

Fulan Diana Kesumawati, Perlindungan Konsumen Dalam Kerangka Hak Atas Informasi bagi Konsumen Pengguna Jasa Transaksi On Line Melalui Internet Banking, Program Pasc Sarjana UniBraw, Malang, 2005

Hadjon, M. Philippus, Perlindungan Hukum bagi Rakyat Indonesia, Bina Ilmu, 1988

RG. Kartosapoetra, Sistematika Hukum Tata Negara, Bina Aksara, Jakarta, 2002,

J.J.H.Bruggink, Refleksi hukum, Citra Aditya Bakti, Bdn, 1996,

Jazim Hamidi, Indikator Peraturan daerah (PERDA) bermasalah yang mengahambat investasi ke daerah, makalah

Jeremy Bentham, Teori Perundang-Undangan, Nusamedia, Bandung, 2006 
Jimly Asshidiqie, Pergeseran-pergeseran Kekausaan Legislatif \& Eksekutif, Universitas Indonesia, Jakarta,2000.

--------, Pergumuklan Peran Pemerintah dan parlemen dalam Sejarah; Telaah Perbandingan Konstitusi berbagai Negara, Jkt, Ui Press, 1996

--------, Perihal Undang-Undang, Konstitusi Pers, Jakarta, 2006.

--------, Hukum tata Negara dan Pilar-Pilar Demokrasi, konstitusi Pers, Jakarta, 2006.

--------, Pembentukan dan Pembuatan Hukum, Universitas Indonesia, Jakarta..

Karea S Fishman, An Overview of Consumer Law dalam Donald P.Rothschild \& David W Carrol, Consumeer Protektion Reporting Service, Maryland, 1986

Kansil CST, Pokok-Pokok Pemerintahan di Daerah, Aksara Baru, Jakarta, 2002.

Muhammad fauzan, Hukum Pemerintahan daerah kajian Tentang Hubungan Keuangan Antara Pusat dan Daerah, PKHKD FH UNSOED dan UII Press, Yogyakarta, 2006.

Nonet.P \& Selznick.P, Law and Sociatety in Transaction T oward Responsif Law, Harper Torchbooks, New York, 1978

Satcipto Rahardjo, ilmu hukum, citra Aditya Bakti, Bdn,2000.

Soerjono Sukanto, Purnadi Purbacaraka, Perihal kaidah Hukum, Citra Aditya Bakti, Bdn, 1993, hlm. 88-89

Soesilo Prayogi, Kamus Hukum Internasional dan Indonesia,2007.

Sudikno Mertokusumo, Mengenal Hukum, Yogjakarta, Liberty, 1999..

--------,Hukum Tata Negara Teknik Perundang-Undangan, BPFE, Yogyakarta, 2006.

Siswanto Sunarno, Hukum Pemerintahan daerah Di Indonesia, Sinar Grafika, Jakarta, 2006

Sirajuddin, Fatkhurahman,zulkarnain, Modul Legislative Drafting, Fakultas Hukum Universitas Widyagama malang, 2005

Sri Pudyatmoho Y, Pengantar Hukum Pajak, 2005.

Solly Lubis, Perkembangan Garis Politik dan Perundang-Undangan Pemerintahan Daerah, Alumni, Bandung, 2001..

Una Sayuti, Pergeseran Kekuasaan Pemerintahan Daerah Menurut Konstitusi Indonesia, UII Press, Cetakan Pertama, Yogyakarta, 2004. 


\section{B. Peraturan dan Perundang-Undangan :}

Republik Indonesia, Undang-Undang Republik Indonesia Nomor 34 Tahun 2000 tentang Pajak Daerah dan Retribusi Daerah.

--------, Undang-Undang Republik Indonesia Nomor 32 Tahun 2004 tentang Pemerintahan Daerah.

--------, Undang-Undang Republik Indonesia Nomor 33 Tahun 2004 tentang Perimbangan Keuangan antara Pusat dan Pemerintah Daerah. 